\title{
Enhancement in cotton (Gossypium hirsutum L.) crop yield by water use efficiency under various planting techniques
}

\section{Liaquat Ali, Wajiha Anum*, Ghulam Hussain, Muhammad Iqbal Shahid}

\author{
Regional Agricultural Research Institute, 63100 Bahawalpur, Pakistan
}

Received: 8 March 2017

Accepted: 3 July 2017

Published online: 11 December 2017

\begin{abstract}
Six experiments were conducted for the enhancement in seed cotton yield by increasing water use efficiency and water savings in case of different planting methods of cotton (Gossypium hirsutum L.) crop during the years 2014 \& 2015, at three different locations in cotton zone of Punjab (Pakistan) province. The planting methods were, flat planting and no earthing up, flat planting and earthing up after $1^{\text {st }}$ irrigation, flat planting and alternate row earthing after $1^{\text {st }}$ irrigation, flat planting in $112.5 / 37.5 \mathrm{~cm}$ apart paired rows and earthing up after $1^{\text {st }}$ irrigation, ridge planting and bed planting. Cotton crop obtained a maximum benefit from the available water at all three locations in case of flat planting with alternate row earthing up $\left(\mathrm{P}_{3}\right)$ by predicting a maximum water use efficiency up to $6.79 \mathrm{~kg} \mathrm{ha}^{-1} \mathrm{~mm}^{-1}$ and maximum seed cotton yield of $3432.50 \mathrm{~kg} \mathrm{ha}^{-1}$. Maximum water savings of $25.60 \%$ was recorded in the same method $\left(\mathrm{P}_{3}\right)$ during the year 2014 , while minimum $(-0.17 \%)$ was observed in ridge planting $\left(\mathrm{P}_{5}\right)$ at location number 1 in the same year.
\end{abstract}

Keywords: Gossypium hirsutum, water use efficiency, water saving, planting methods, alternate row earthing up

\section{Introduction}

Pakistan is predominantly an agricultural country(Akhtar 2006; Saeed et al. 2015) and prosperity of the people depend largely upon the successful cultivation of crops such as wheat, cotton, rice, sugarcane and maize(Ahmad et al. 2015; Raheem et al. 2016).)Among these, cotton is a crop of high national importance (Briddon and Markham 2000; Bakhsh et al. 2005) because it earns substantial foreign exchange through the export of raw cotton, yarn and finished products (Muhammad et al. 2013; Latif and Javid 2014; Anonymous 2005). In addition, cotton crop provides livelihood to millions of people who are engaged in the textile industry either directly or indirectly (Noman et al. 2013; Latif and Javid 2014).

Realizing the immense importance of cotton plant in building the economy of Pakistan, it has always been the objective of extensive research to improve the yield potential of the crop under local environmental conditions and better utilization of the source available for successful crop production. Successful production of cotton crop totally depends upon the availability of the irrigation water which

\footnotetext{
* Corresponding author: W. Anum

e-mail: wajiha_anum@live.com
} 
either comes from canal or tube well. Irrigated agriculture is facing growing competition for low cost, high quality water (Howell 2001). High quality irrigation water is being deficit day by day and the world is looking for water saving agriculture, it refers to farming practices, able to take full advantage of the available irrigation facilities (Xi.Ping Deng et al. 2004). Water saving agriculture intends to raise the water utilization rate and water use efficiency that is to achieve a high economic yield on irrigated farm land with the minimum input of water at both the public and private levels (Hobbs et al. 2008; Davies et al. 2011)

Water use efficiency (WUE) is a potential selection criterion for improving yield under water stress and it evaluates the way and depth of water application, whether it was used at the best level by the crop. Usually cotton crop uses less water per hectare than other agricultural industry but exception of horticulture (Hearn 2000). Water use efficiency is not simply water saving irrigation but it is comprehensive exercise using every possible water saving measures in whole farm production, including the full use of natural precipitation as well as the efficient management of an irrigation network through a suitable planting method. Reducing the row spacing resulted in increase light interception, growth rate, total biomass production, and water use efficiency (Staggenborg et al. 1992). Better irrigation water use efficiency can be achieved through the adoption of irrigation best management practices (Goyne and McIntyre 2001). According to McAlavy (2004), adoption of subsurface irrigation on smaller acreage can increase cotton yield, water use efficiency and return per acre.

Planting methods are an important factor which affects crop growth development and finally the crop yield. Furrows and alternate furrows irrigation systems (flat planting method with every row and alternate row earthing up) save up to $50 \%$ irrigation water and enhance seed cotton yield as compare to flood irrigation (flat planting with no earthing up) (Aujla et al. 1991; Sagare and Bongle 1993; Wiese et al. 1994). Makhdum et al. (2001) found 32\% water savings and minimized salinity hazards in bed and furrow planting system.

Adoption of appropriate planting method and water management for successful crop production are the most critical problems specially in cotton growing areas of Pakistan, where the underground water is almost brackish and source of irrigation is only the canal water, which is becoming scarcer day by day and it is a dire need to utilize every inch of available water in an efficient way.

Systematic work has not been done in the past to evaluate various sowing/planting methods for water savings and water use efficiency. A contrary also exists for water savings in case of newly adopted bed planting and flat planting system. Therefore the present study was conducted to evaluate the most suitable method of planting cotton crop to develop water use efficiency, water savings \& enhancement in seed cotton yield per unit of land.

\section{Materials and Methods}

Six experiments were conducted during the years, 2014 and 2015, at three different locations: 1., Agronomic Research Station, Bahawalpur;

2. Farmers field in District Bahawalnagar;

3. Farmers field at Ahmed Pur East.

Each location was at a distance of almost $80 \mathrm{~km}$ from other and in different agro-ecological conditions. Two cotton varieties(with different water requirements), BH-160 and CIM-506 were planted in 2nd fortnight of May, under six different planting methods viz., flat planting and no earthing up (P1),flat planting and every row earthing up after 1st irrigation (P2), flat planting and alternate row earthing up after 1st irrigation (P3), flat planting in 112.5/37.5 cm apart paired rows and every row earthing up after 1st irrigation (P4), ridge planting (P5) and bed planting (P6). The trial was laid out in split plot arrangement giving more importance to planting methods and the plot size was $4.5 \mathrm{~m} \times 15 \mathrm{~m}$. 
1st irrigation was applied to P1, P2, P3 and P4 at 35 days after planting and earthing up was done according to the treatments, P5 and P6 were irrigated just after the planting. After that subsequent irrigations were applied according to the need of crop (physical appearance of crop plants for irrigation) and planting methods. Each time a measured quantity of irrigation water was applied with the help of cut throat flume using the formula $\mathrm{Qt}=\mathrm{Ad}$ or $\mathrm{t}=\mathrm{Ad} / \mathrm{Q}$ and each irrigation was $7.5 \mathrm{~cm}$ in depth. Seed cotton yield data were recorded and water use efficiency was calculated using the formula given by Viets (1962), as (Eq. 1):

$$
W U E=\frac{\text { crop yield (economic yield) }}{\text { water used to produce the yield }}
$$

Water saving \%age was also calculated in case of different planting methods for each year and for all locations, against flat planting and no earthing up (flood irrigation system).

Data were analyzed statistically by using Fisher's analysis of variance techniques and least significant difference (LSD) at 5\% probability was applied to compare the differences among treatment means (Steel et al. 1997).

\section{Results and Discussions}

\subsection{Economic yield and Water use efficiency}

Crop water use efficiency is an important consideration where irrigation water resources are limited or diminishing and where rainfall is a limiting factor. Additionally, recent increases in energy prices has trigger the question in minds of many irrigated producers that how to manage inputs to maximize efficiency of their water resources. Regardless of the situation, it's crucial that growers have to get the most out of every inch of available water, whether that water comes through irrigation, rainfall, or both.

Water use efficiency and seed cotton yield in relation to different planting methods (Tab. 1) revealed that the crop obtained a maximum benefit from the water available in flat planting with alternate row earthing $\left(\mathrm{P}_{3}\right)$ at all three locations, giving maximum seed cotton yield of 3432, 3325, 2655, $\mathrm{kg} \mathrm{ha}^{-1}$ and maximum water use efficiency of $6.79,6.34,5.13, \mathrm{~kg} \mathrm{ha}^{-1} \mathrm{~mm}^{-1}$ at locations 1,3 and 2 respectively during the year 2014. Paired row planting and earthing up after $1^{\text {st }}$ irrigation $\left(\mathrm{P}_{4}\right)$ was also statistically at par with alternate row earthing $\left(\mathrm{P}_{3}\right)$, while flat planting and no earthing $\left(\mathrm{P}_{1}\right)$ accompanied with ridge planting method $\left(\mathrm{P}_{5}\right)$ was statistically at lowest position in water use efficiency at all three locations and with all the experiments. Similar trend was observed during the year 2015 at all the locations and with all the experiments (Tab. 2). These findings are in consonance with those of Hearn (2000), Ertek and Kanber (2001), Goyne and McIntyre (2001), Terry A. Howell (2001) and Hood (2002) while McAlavy (2004) Xi-ping Deng et al. (2004) and Bhattari (2005) reported that crop water use efficiency can be enhanced by sprinkler or drip irrigation systems.

Figs. 3 and 4 indicates that linear regression and co-relation between water use efficiency and seed cotton yield in case of different planting methods, predicting the better utilization of irrigation water by the crop plants to produced the maximum economic yield in case of various planting systems.

\subsection{Water saving \%age}

The data regarding water savings in case of different planting methods, in comparison with flood irrigation or flat planting with no earthing up is given in the Tab. 3. A glance on the data indicates that during the year 2014, a maximum water saving of 25.60 percent was recorded from $\mathrm{P}_{3}$, the flat planting and alternate row earthing after 1st irrigation at location number 3, while 25.21 percent and 
L. Ali et al.

23.26 percent water saving was recorded in the same planting method at location number 2 and location number 1 respectively, Followed by paired row planting and earthing up after $1^{\text {st }}$ irrigation ( $\mathrm{p}_{4}$ ), while minimum percentage was recorded in ridge planting method $\left(\mathrm{p}_{5}\right)$ at all three locations. Trend was similar during the year 2015, the maximum water saving was noted in flat planting with alternate row earthing after $1^{\text {st }}$ irrigation $\left(\mathrm{p}_{3}\right)$ as 23.19 percent at location number 2, 22.43 percent at location number 3 and 20.34 percent at location number 1 . This method was followed by paired row planting $\left(\mathrm{p}_{4}\right)$ by water saving as 21.23 percent at location number 3, 19.15 percent at location number 2 and 18.29 percent at location number 1 , while minimum water saving through out the crop growing period was noted in ridge planting method $\left(\mathrm{p}_{5}\right)$ and flat planting with every row earthing up $\left(\mathrm{p}_{2}\right)$.

These results are in line with the previous researchers as Aujla et al. (1991) Khalid et al. (1999) Khan et al. (1999) and Li-Song (2005). Figs. 1 and 2 shows the negative co-relation between total water applied in different planting methods and seed cotton yield, most probably due to great variation in water used in case of various planting methods. Trend was the same at all three locations and for both the years (2014 and 2015).

Tab. 1 Water use efficiency and seed cotton yield in relation to different planting methods (2014).

Experiment No.1, Location-1

\begin{tabular}{lccc}
\hline $\begin{array}{l}\text { Planting } \\
\text { Methods }\end{array}$ & $\begin{array}{c}\text { Seed Cotton Yield } \\
\left(\text { Kgha }^{-\mathbf{1}}\right)\end{array}$ & $\begin{array}{c}\text { Total Water Used } \\
(\mathbf{I}+\mathbf{R})(\mathbf{m m})\end{array}$ & $\begin{array}{c}\text { Water Use Efficiency } \\
\left(\mathbf{k g ~ h a}^{\mathbf{1}} \mathbf{~ m m}^{\mathbf{- 1}}\right)\end{array}$ \\
\hline P1 & $3173.00 \mathrm{~b}$ & 636 & $4.98 \mathrm{c}$ \\
P2 & $3421.00 \mathrm{a}$ & 623 & $5.49 \mathrm{~b}$ \\
P3 & $3432.50 \mathrm{a}$ & 506 & $6.79 \mathrm{a}$ \\
P4 & $3355.50 \mathrm{a}$ & 529 & $6.34 \mathrm{a}$ \\
P5 & $3149.00 \mathrm{~b}$ & 638 & $4.94 \mathrm{c}$ \\
P6 & $3175.00 \mathrm{~b}$ & 538 & $5.30 \mathrm{~b}$ \\
\hline LSD value & 84.89 & - & 0.50 \\
\hline
\end{tabular}

Experiment No.2, Location-2

\begin{tabular}{lccc}
\hline $\begin{array}{l}\text { Planting } \\
\text { Methods }\end{array}$ & $\begin{array}{c}\text { Seed Cotton Yield } \\
\left(\mathbf{K g h a}^{-1}\right)\end{array}$ & $\begin{array}{c}\text { Total Water Used } \\
(\mathbf{I}+\mathbf{R})(\mathbf{m m})\end{array}$ & $\begin{array}{c}\text { Water Use Efficiency } \\
\left(\mathbf{k g ~ h a}^{\mathbf{1}} \mathbf{~ m m}^{-\mathbf{1}}\right)\end{array}$ \\
\hline P1 & $2569.00 \mathrm{~d}$ & 664 & $3.87 \mathrm{~b}$ \\
P2 & $2639.50 \mathrm{~b}$ & 642 & $4.12 \mathrm{~b}$ \\
P3 & $2655.50 \mathrm{a}$ & 518 & $5.13 \mathrm{a}$ \\
P4 & $2609.00 \mathrm{c}$ & 546 & $4.78 \mathrm{a}$ \\
P5 & $2538.00 \mathrm{e}$ & 652 & $3.90 \mathrm{~b}$ \\
P6 & $2498.50 \mathrm{f}$ & 604 & $4.14 \mathrm{~b}$ \\
\hline LSD value & 5.88 & - & 0.63 \\
\hline
\end{tabular}

Experiment No.3, Location-3

\begin{tabular}{|c|c|c|c|}
\hline Treatments & $\begin{array}{c}\text { Seed Cotton Yield } \\
\left(\mathrm{Kgha}^{-1}\right)\end{array}$ & $\begin{array}{l}\text { Total Water Used } \\
(\mathbf{I}+\mathrm{R})(\mathbf{m m})\end{array}$ & $\begin{array}{c}\text { Water Use Efficiency } \\
\left(\mathrm{kg} \mathrm{ha}^{-1} \mathrm{~mm}^{-1}\right)\end{array}$ \\
\hline P1 & $3162.50 \mathrm{~d}$ & 673 & $4.70 \mathrm{c}$ \\
\hline P2 & $3312.50 \mathrm{c}$ & 649 & $5.11 b c$ \\
\hline $\mathbf{P 3}$ & $3325.00 \mathrm{a}$ & 525 & $6.34 \mathrm{a}$ \\
\hline P4 & $3320.00 \mathrm{~b}$ & 553 & $6.00 \mathrm{a}$ \\
\hline P5 & $3323.00 \mathrm{ab}$ & 653 & $5.09 \mathrm{bc}$ \\
\hline P6 & $3311.00 \mathrm{c}$ & 615 & $5.39 \mathrm{~b}$ \\
\hline LSD value & 4.32 & - & 0.60 \\
\hline
\end{tabular}


L. Ali et al.

Tab. 2 Water use efficiency and seed cotton yield in relation to different planting methods (2015).

Experiment No.1, Location-1

\begin{tabular}{lccc}
\hline Treatments & $\begin{array}{c}\text { Seed Cotton Yield } \\
\left(\mathbf{K g h a}^{-\mathbf{1}}\right)\end{array}$ & $\begin{array}{c}\text { Total Water Used } \\
(\mathbf{I}+\mathbf{R})(\mathbf{m m})\end{array}$ & $\begin{array}{c}\text { Water Use Efficiency } \\
\left(\mathbf{k g ~ h a}^{-\mathbf{1}} \mathbf{~ m}^{-\mathbf{1}}\right)\end{array}$ \\
\hline P1 & $2714.00 \mathrm{c}$ & 650 & $4.17 \mathrm{~d}$ \\
P2 & $2911.50 \mathrm{ab}$ & 637 & $4.57 \mathrm{c}$ \\
P3 & $2991.00 \mathrm{a}$ & 531 & $5.63 \mathrm{a}$ \\
P4 & $2819.00 \mathrm{c}$ & 543 & $5.19 \mathrm{~b}$ \\
P5 & $2863.00 \mathrm{~b}$ & 632 & $4.53 \mathrm{~cd}$ \\
P6 & $2892.50 \mathrm{~b}$ & 594 & $4.87 \mathrm{bc}$ \\
\hline LSD value & 45.69 & - & 0.39 \\
\hline
\end{tabular}

Experiment No.2, Location-2

\begin{tabular}{|c|c|c|c|}
\hline $\begin{array}{l}\text { Planting } \\
\text { Methods }\end{array}$ & $\begin{array}{c}\text { Seed Cotton Yield } \\
\left(\text { Kgha }^{-1}\right)\end{array}$ & $\begin{array}{l}\text { Total Water Used } \\
(\mathbf{I}+\mathbf{R})(\mathbf{m m})\end{array}$ & $\begin{array}{l}\text { Water Use Efficiency } \\
\quad\left(\mathrm{kg} \mathrm{ha}^{-1} \mathbf{m m}^{-1}\right)\end{array}$ \\
\hline P1 & 2547.50 & 700 & $3.64 \mathrm{~b}$ \\
\hline P2 & 2617.50 & 684 & $3.83 \mathrm{~b}$ \\
\hline P3 & 2617.00 & 562 & $4.66 \mathrm{a}$ \\
\hline P4 & 2610.50 & 586 & $4.46 \mathrm{a}$ \\
\hline P5 & 2519.00 & 675 & $3.74 \mathrm{~b}$ \\
\hline P6 & 2507.50 & 632 & $3.97 \mathrm{~b}$ \\
\hline LSD value & - & - & 0.37 \\
\hline
\end{tabular}

Experiment No.3, Location-3

\begin{tabular}{|c|c|c|c|}
\hline Treatments & $\begin{array}{c}\text { Seed Cotton Yield } \\
\left(\mathrm{Kgha}^{-1}\right)\end{array}$ & $\begin{array}{l}\text { Total Water Used } \\
(\mathrm{I}+\mathrm{R})(\mathrm{mm})\end{array}$ & $\begin{array}{c}\text { Water Use Efficiency } \\
\left(\mathrm{kg} \mathrm{ha}^{-1} \mathbf{m m}^{-1}\right)\end{array}$ \\
\hline P1 & 2708.50 & 648 & $4.18 \mathrm{~b}$ \\
\hline P2 & 2738.50 & 633 & $4.33 \mathrm{~b}$ \\
\hline P3 & 2746.00 & 517 & $5.32 \mathrm{a}$ \\
\hline P4 & 2729.00 & 524 & $5.21 \mathrm{a}$ \\
\hline P5 & 2692.50 & 643 & $4.19 \mathrm{~b}$ \\
\hline P6 & 2701.50 & 596 & $4.54 \mathrm{~b}$ \\
\hline LSD value & - & - & 0.52 \\
\hline
\end{tabular}

\section{Conclusion}

Pakistan and other arid regions are facing great water deficit which results in poor yield in the most economically important crops of Pakistan. As cotton crop is the main source of income in the fiber industry thus keeping its production in pace with the emergent population is the main target for the agriculturalists. Cotton crop requires the adequate and well managed water for its growth and development, in case of limited water resources especially in arid regions like Pakistan, the need to save water has raised the need to save it with minimum economical input. For this the planting techniques can render surprisingly positive results by increasing the water use efficiency in cotton crop. Flat planting with alternate row earthing up can save up to $25 \%$ of the total water use $\mathrm{n}$ cotton crop. It is concluded that by implementing new planting techniques in cotton crop water savings can be achieved.Further more arid regions where rainfall is limited can obtain maximum benefit out of various planting methods. 
L. Ali et al.

\section{Authors contribution}

Dr. Liaquat Ali is the main author who has conducted the original research in two years.

Wajiha anum is working as assistant research officer under the supervision of Dr. liaquat ali and is the corresponding author of the manuscript and has done the write up of the manuscript while Ghulam hussain has helped in analysis, graphical and tabular presentation of the data with as well as assisted in write up.

a

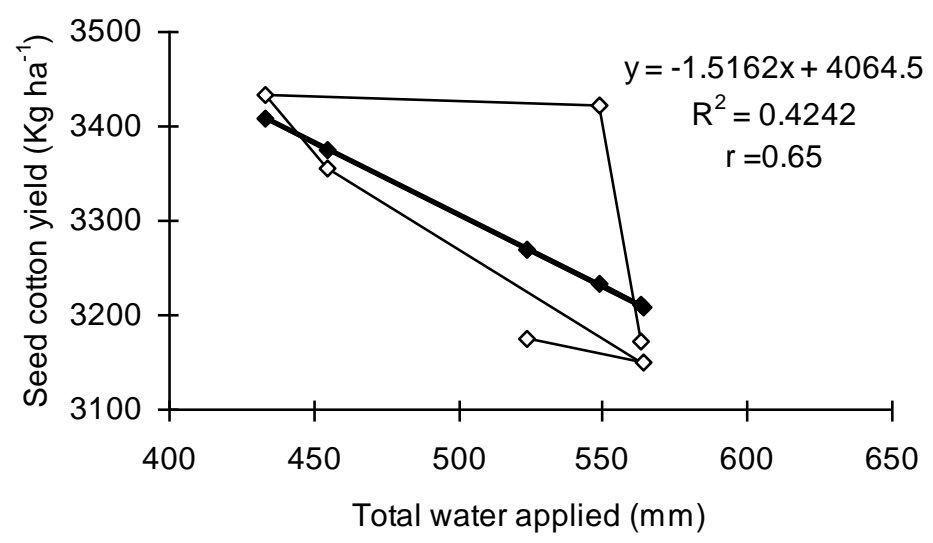

b
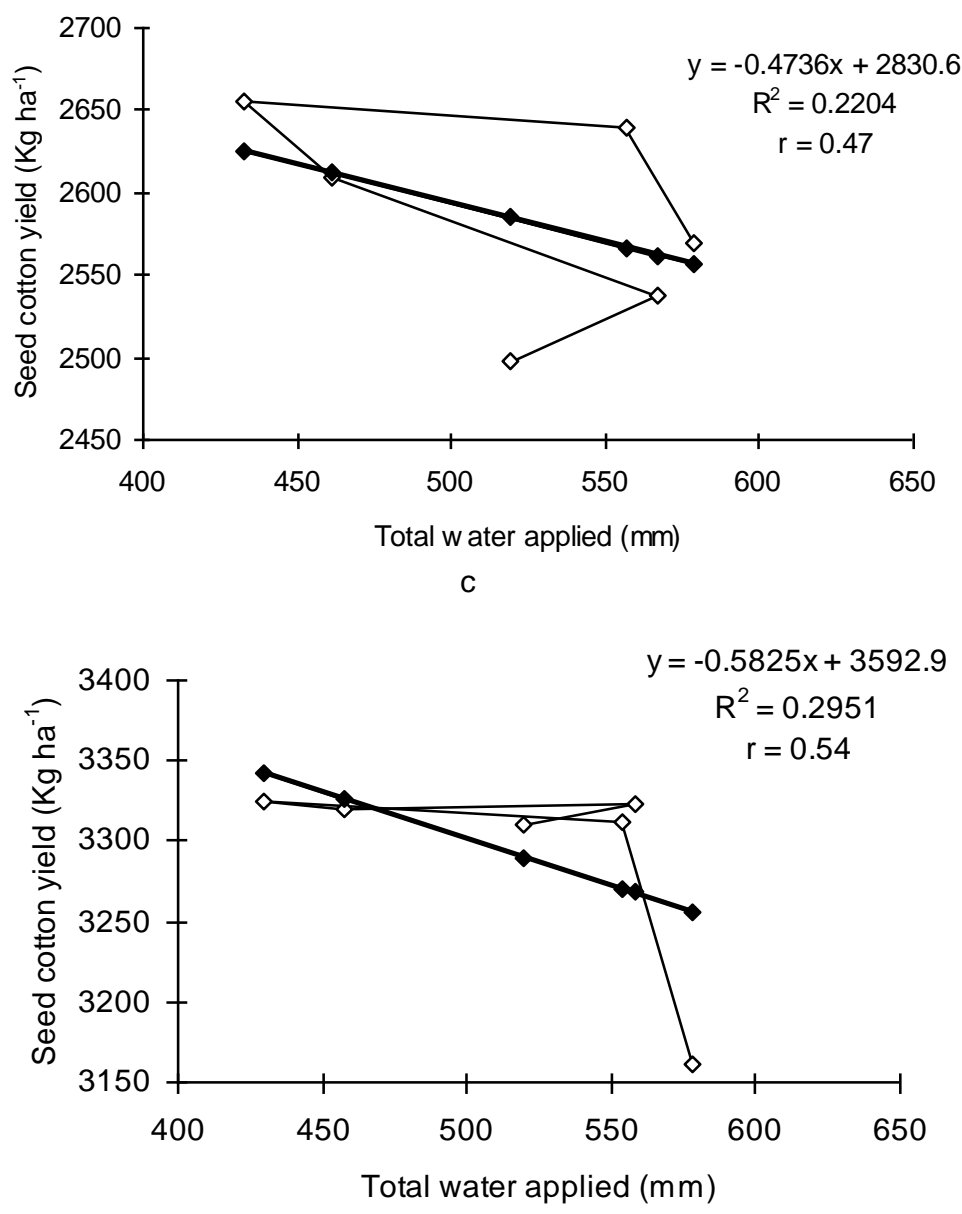

Fig. 1 Relationship between yield and total water applied at location 1 (a), 2 (b), 3 (c) during 2004. 
Environment, Earth and Ecology Vol. 1 No. 2 (2017), 6 - 16 L. Ali et al.

a

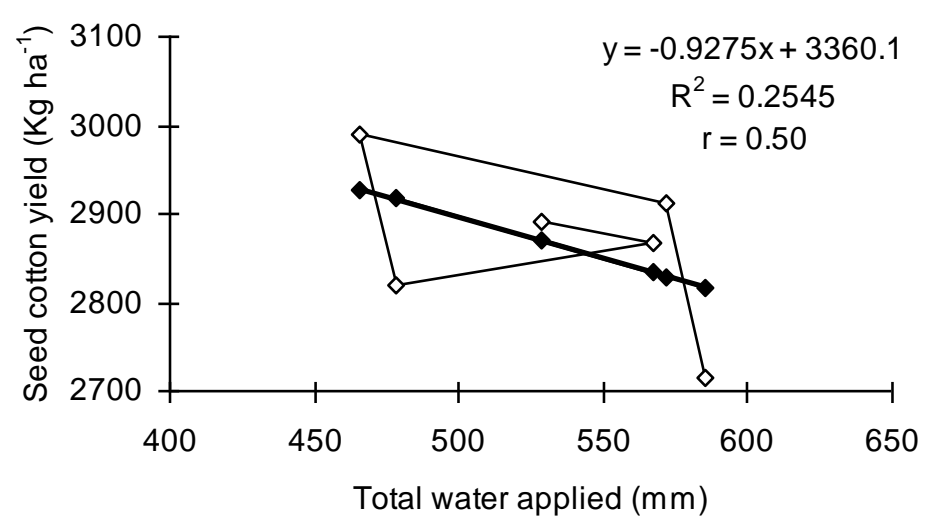

b

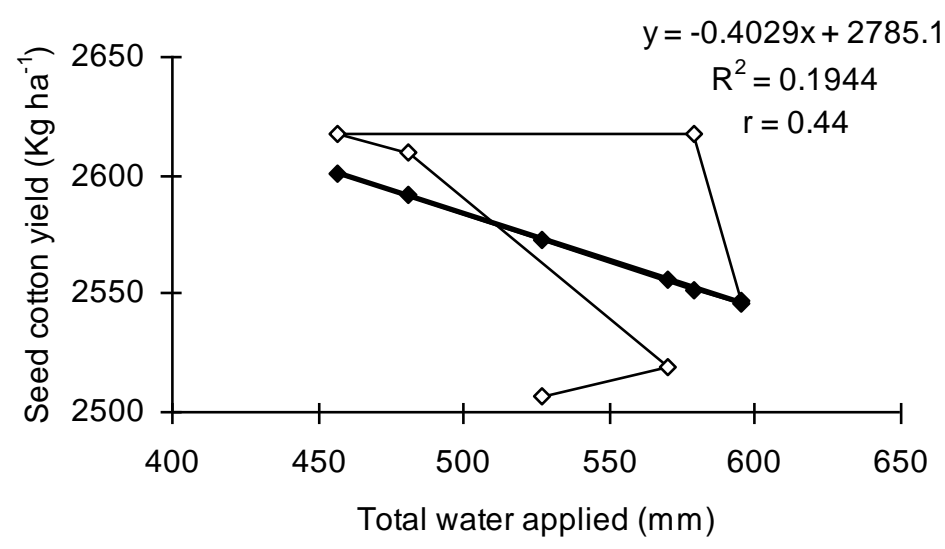

C

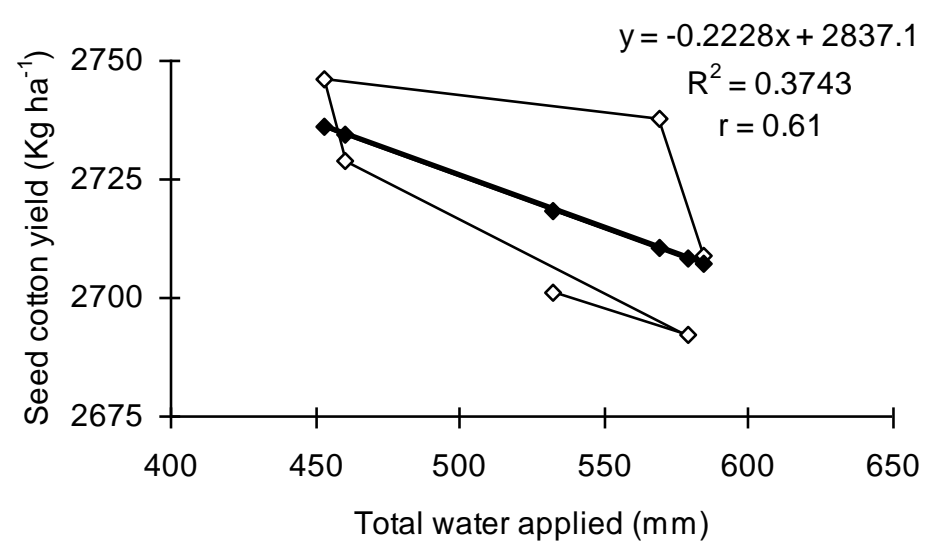

Fig. 2 Relationship between yield and total water applied at location 1 (a), 2 (b), 3 (c) during 2005. 
Environment, Earth and Ecology Vol. 1 No. 2 (2017), 6 - 16 L. Ali et al.

a

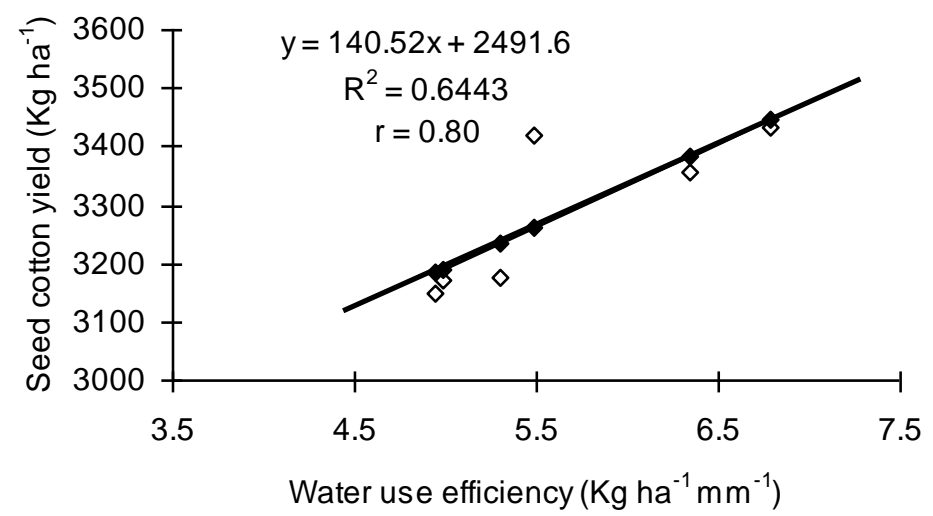

b

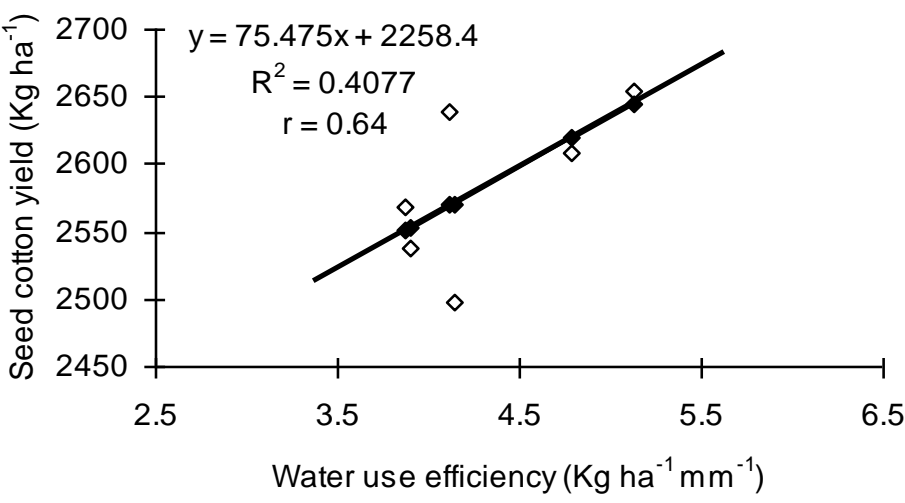

C

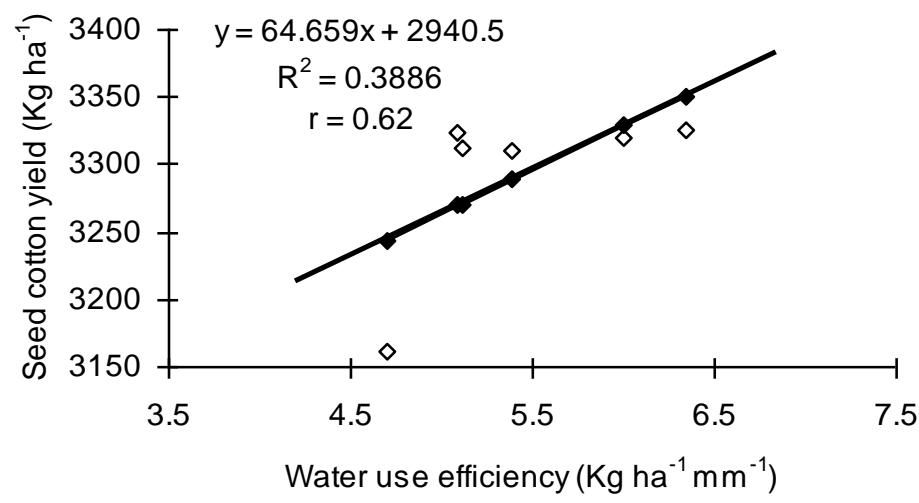

Fig. 3 Relationship between yield and water use efficiency at location 1 (a), 2 (b), 3 (c) during 2004. 
Environment, Earth and Ecology Vol. 1 No. 2 (2017), 6 - 16 L. Ali et al.

a

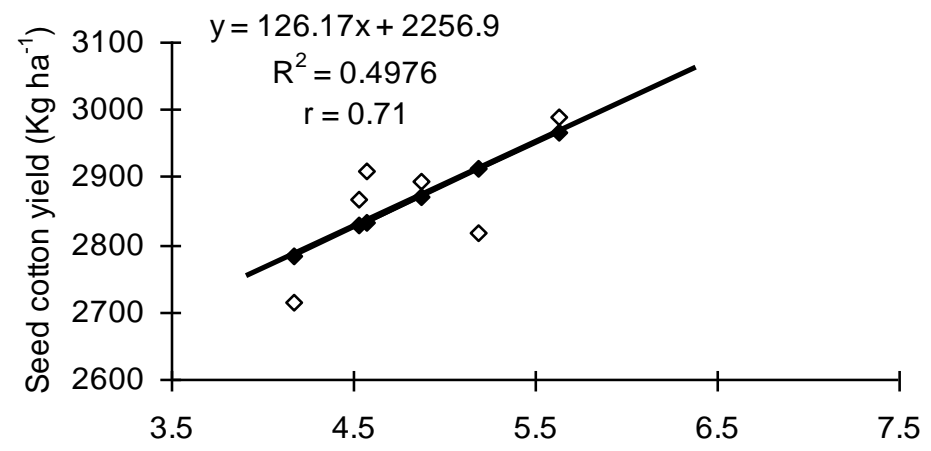

Water use efficiency $\left(\mathrm{Kg} \mathrm{ha}^{-1} \mathrm{~mm}^{-1}\right)$

b

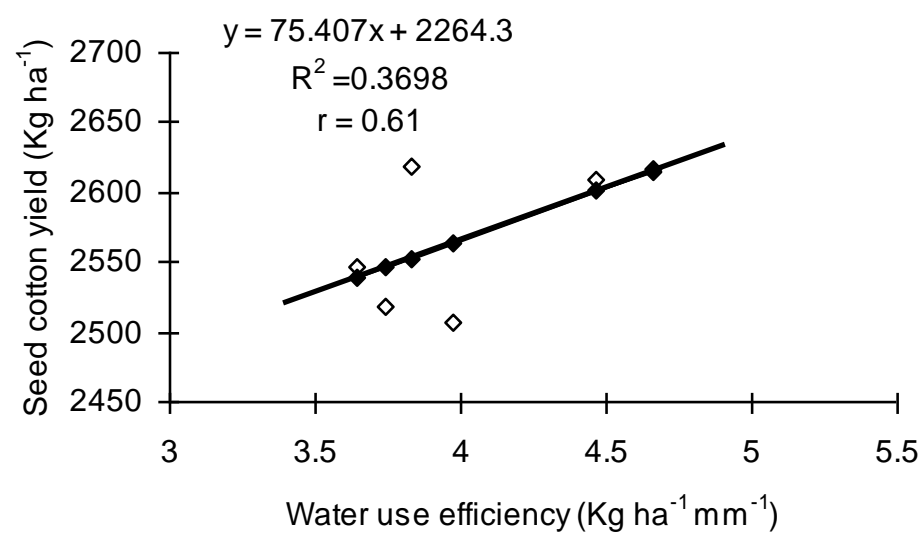

C

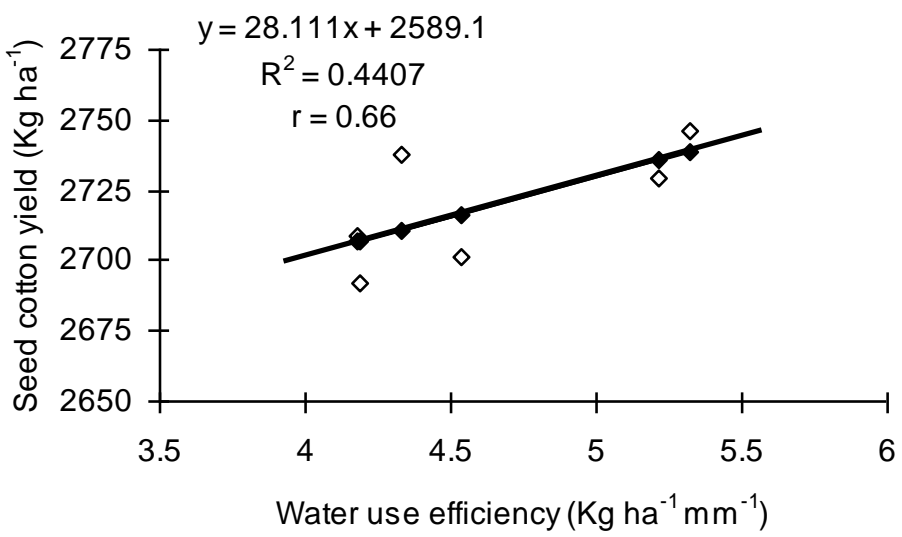

Fig. 4 Relationship between yield and water use efficiency at location 1 (a), 2 (b), 3 (c) during 2005. 
Environment, Earth and Ecology Vol. 1 No. 2 (2017), 6 - 16

L. Ali et al.

Tab. 3 Water Saving Percentage during the Year: 2014 and 2015.

2014

\begin{tabular}{lcccccc}
\hline Planting Methods & \multicolumn{2}{c}{ Location 1 } & \multicolumn{2}{c}{ Location 2 } & \multicolumn{2}{c}{ Location 3 } \\
\cline { 2 - 6 } & $\begin{array}{c}\text { Total water } \\
\text { applied } \\
(\mathbf{m m})\end{array}$ & $\begin{array}{c}\text { Water } \\
\text { saving } \\
\text { percentage }\end{array}$ & $\begin{array}{c}\text { Total water } \\
\text { applied } \\
(\mathbf{m m})\end{array}$ & $\begin{array}{c}\text { Water } \\
\text { saving } \\
\text { percentage }\end{array}$ & $\begin{array}{c}\text { Total water } \\
\text { applied } \\
\text { (mm) }\end{array}$ & $\begin{array}{c}\text { Water } \\
\text { saving } \\
\text { percentage }\end{array}$ \\
\hline $\begin{array}{l}\text { P1 Flat planting and } \\
\text { no earthing }\end{array}$ & 563 & - & 579 & - & 578 & - \\
$\begin{array}{l}\text { P2 Flat planting and } \\
\text { earthing after Ist Irri. }\end{array}$ & 549 & 2.49 & 557 & 3.79 & 554 & 4.15 \\
$\begin{array}{l}\text { P3 Flat planting and } \\
\text { alternate row }\end{array}$ & 432 & 23.26 & 433 & 25.21 & 430 & 25.60 \\
$\begin{array}{l}\text { Earthing after Ist Irri. } \\
\text { P4 Flat planting in } \\
\text { paired rows and } \\
\text { earthing after Ist irri. }\end{array}$ & 455 & 19.18 & 461 & & & \\
$\begin{array}{l}\text { P5 Ridge planting } \\
\text { P6 Bed planting }\end{array}$ & 564 & -0.17 & 567 & 20.37 & 458 & 20.76 \\
\hline Mean & 524 & 6.92 & 519 & 10.36 & 520 & 3.46 \\
\hline
\end{tabular}

2015

\begin{tabular}{lcccccc}
\hline Planting Methods & \multicolumn{2}{c}{ Location 1 } & \multicolumn{2}{c}{ Location 2 } & \multicolumn{2}{c}{ Location 3 } \\
\cline { 2 - 5 } & $\begin{array}{c}\text { Total water } \\
\text { applied } \\
(\mathbf{m m})\end{array}$ & $\begin{array}{c}\text { Water } \\
\text { saving } \\
\text { percentage }\end{array}$ & $\begin{array}{c}\text { Total water } \\
\text { applied } \\
\text { (mm) }\end{array}$ & $\begin{array}{c}\text { Water } \\
\text { saving } \\
\text { percentage }\end{array}$ & $\begin{array}{c}\text { Total water } \\
\text { applied } \\
\text { (mm) }\end{array}$ & $\begin{array}{c}\text { Water } \\
\text { saving } \\
\text { percentage }\end{array}$ \\
\hline $\begin{array}{l}\text { P1 Flat planting and } \\
\text { no earthing }\end{array}$ & 585 & - & 595 & - & 584 & - \\
$\begin{array}{l}\text { P2 Flat planting and } \\
\text { earthing after Ist Irri. }\end{array}$ & 572 & 2.22 & 579 & 2.68 & 569 & 2.56 \\
$\begin{array}{l}\text { P3 Flat planting and } \\
\text { alternate row }\end{array}$ & 466 & 20.34 & 457 & 23.19 & 453 & 22.43 \\
$\begin{array}{l}\text { earthing after Ist Irri. } \\
\begin{array}{l}\text { P4 Flat planting in } \\
\text { paired rows and }\end{array}\end{array}$ & 478 & 18.29 & 481 & 19.15 & 460 & 21.23 \\
earthing after Ist irri. & & & & & & \\
$\begin{array}{l}\text { P5 Ridge planting } \\
\text { P6 Bed planting }\end{array}$ & 567 & 3.07 & 570 & 4.20 & 579 & 0.85 \\
\hline Mean & 529 & 9.57 & 527 & 11.42 & 532 & 8.90 \\
\hline
\end{tabular}

\section{References}

Ahmad A, Ashfaq M, Rasul G, Wajid SA, Khaliq T, Rasul F, Naqvi SAA (2015) Impact of climate change on the rice-wheat cropping system of Pakistan. Handbook of Climate Change and Agroecosystems: The Agricultural Model Intercomparison and Improvement Project Integrated Crop and Economic Assessments, Part, 2.

Akhtar MR (2006) Impact of resource conservation technologies for sustainability of irrigated agriculture in Punjab-Pakistan. Journal of Agricultural Research (Pakistan).

Anonymous (2005) Pakistan Economic survey, Government of Pakistan. Finance Division. Economic Advisor's wing. Islamabad. pp.11.

Aujla MS, Singh CJ, Vashist KK, Sandhu BS (1991) Evaluation of methods for irrigation of cotton in a canal irrigated area of South-West Punjab, India. Arid Soil Research and rehabilitation. 5(3).

Bakhsh KHUDA, Hassan I, Maqbool A (2005) Factors affecting cotton yield: a case study of Sargodha (Pakistan). Journal of Agriculture \& Social Sciences. 1(4): 332-334.

Bhattarai SP (2005) The physiology of water use efficiency of crops subjected to subsurface drip irrigation, oxygation and salinity in a heavy clay soil. Ph.D. dissertation, Central Queensland Uni. Rockhampton, Australia. 
L. Ali et al.

Briddon RW, Markham PG (2000) Cotton leaf curl virus disease. Virus research. 71(1): 151-159.

Davies WJ, Zhang J, Yang J, Dodd IC (2011) Novel crop science to improve yield and resource use efficiency in water-limited agriculture. The Journal of Agricultural Science. 149: 123-131.

Ertek A, Kanber R (2001) Water use efficiency and change in the yield response factor of cotton irrigated by an irrigation drip system. Turkish J. Agri. and Forestry. 25(2): 111-118.

Goyne PJ, McIntyre GT (2001) Improving on farm irrigation water use efficiency in the Queensland cotton and grain Industries. A project of QDPI, Agency for food and fiber sciences, Farming system Institute and Australian Cotton CRC.

Hearn B (2000) The science of water balance: Why do we need to know?.In: Proceddings $10^{\text {th }}$ Australian Cotton Conference, Brisbane, Queensland, Australia. pp 351-360.

Hobbs PR, Sayre K, Gupta R (2008) The role of conservation agriculture in sustainable agriculture. Philosophical Transactions of the Royal Society B: Biological Sciences. 363: 543-555.

Hood S (2002) Rural water use efficiency. Real water use efficiency and the opportunity.In: Proceedings $11^{\text {th }}$ Australian Cotton Conference, Brisbane, Queensland, Australia.pp 285-295.

Howell TA (2001) Enhancing water use efficiency in irrigated agriculture. Agron. J. 93: 281-289.

Khalid HK, Rana MA, Arshad M (1999) Alternate furrow irrigation for enhancing water use efficiency in cotton. Pak. J. Agri. Sci. 36(3-4): 175-177 [Cab Absts., 1998-2000].

Khan KH, Rana MA, Arshad M (1999) Alternate furrow irrigation for enhancing water use efficiency. Pak. J. Agri. Sci. 36(3): 173-175.

Latif R, Javid AY (2014) Determinants for the Demand and Supply of Textile Exports of Pakistan (No. id: 5935).

Li-Song T, Li Y, Zang J (2005) Physiological and yield responses of cotton under partial root zone irrigation. Field Crops Research. 94: 214-223.

Makhdum MT, Chaudhry FI, Ahmad F (2001) Management of salt effected soils for sustainable cotton production. The Pak. Cotton growers. 5(2): 8-9.

McAlavy TW (2004) Researchers Investigate cotton irrigation strategies. Agricultural Communications Taxas, A \& M University System, 2112 TAMUS.

Muhammad I, Nadeem K, Akmal A (2013) Value chain analysis of ginning and spinning sector of textile industry of Pakistan. In: Proceeding ASBBS. 20(1),p 789.

Noman M, Batool SA, Chaudhry MN (2013) Economic and employment potential in textile waste management of Faisalabad. Waste Management \& Research. 31(5):485-493.

Raheem A, Hassan MY, Shakoor R (2016) Bioenergy from anaerobic digestion in Pakistan: Potential, development and prospects. Renewable and Sustainable Energy Reviews. 59: 264-275.

Saeed MA, Irshad A, Sattar H, Andrews GE, Phylaktou HN, Gibbs BM (2015) Agricultural Waste Biomass Energy Potential In Pakistan. In: Proceedings of the International Conference held in Shanghai, PR China. Leeds.

Sagare BN, Bhongle AT (1993) Soil moisture storage and productivity of cotton as influenced by broad base furrows. Agropedology. 3: 117-120.

Staggenborg SA, Krieg DR, Harris JL (1992) Water, nitrogen and radiation use efficiency of cotton production systems. In: Proceedings Belt wide Cotton, conference 3, p 1029-1030.

Steel RGD, Torrie JH, Dickey DA (1997) Principles and procedures of statistics. McGraw Hill Book Co., Inc. New York.

Viets FG Jr. (1962) Fertilizers and the efficient use of water. Adv. Agron. 14: 223-264.

Wiese AF, Harman WL, Regier C (1994) Economic evaluation of conservation tillage systems for dry level and irrigated cotton (Gossypium hirsutum) in the Southern great plains. Weed Science. 42(2): 316-321.

Xi-ping Deng, Shan L, Zhang H, Turner NC (2004) Improving Agricultural water use efficiency in arid and semiarid areas of China. "New directions for a diverse planet".In: Proceedings of $4^{\text {th }}$ International Crop Science Conference, Brisbane, Australia. 